\title{
The Effect of Circuit Training on the Improvement of Dribbling Ability of Junior Players
}

\author{
Pahri Novera \\ Sport Education Program \\ Faculty of Sport Science \\ Padang State University \\ Padang, Indonesia \\ pahrinovera@gmail.com
}

\begin{abstract}
This research aims to examine the effect of circuit training on the improvement of junior players dribbling ability. The research method used is an experimental method with a sample of 30 students. The study began with a pre-test and then conducted treatment for six weeks with a frequency of exercise 3 times a week, then ended with a post-test.

In this research, hypothesis testing uses a t-test that is processed manually and shows that there is an effect of Circuit Training Exercises on Improving the Dribbling Ability of Football Players Aged 12-14 Years at Kerinci 6 Public Middle School. It can be seen from the comparison of tcount with ttable $(14,519>$ ttable 1,699), this states that Ho: rejected and Ha: accepted, at the $95 \%$ confidence level or $\alpha=0.05$

From the data analysis, it turns out that the hypotheses put forward in this study were accepted as correct. Thus it was concluded that there was a significant effect of the Circuit Training Exercise on Increasing the Dribbling Ability of Football Players Aged 12-14 Years Old at Kerinci 6 Public Middle School.
\end{abstract}

Keywords-Circuit Training Exercise, Dribbling Ability

\section{INTRODUCTION}

One of the efforts to improve the quality of quality Indonesian human resources is through sports, this is in accordance with the objectives of the national sports listed in RI Law No. 3, (2005) [1] concerning the national sports system which reads: "Maintaining and improving health and fitness, achievement, human quality, instilling moral values and noble morals, sportsmanship, discipline, strengthening and fostering national unity and integrity, strengthening national security, and elevating the nation's dignity, dignity and honor".

"Memelihara dan meningkatkan kesehatan dan kebugaran, prestasi, kualitas manusia, menanamkan nilai moral dan akhlak mulia, sportivitas, disiplin, mempererat dan membina persatuan dan kesatuan bangsa, memperkukuh ketahanan nasional, serta mengangkat harkat, martabat, dan kehormatan bangsa".

From the description it appears that among the various goals and objectives of Indonesian sports activities one of them is fostering achievement. This means that sports activities in Indonesia are not only for physical fitness, or recreation, but must also think towards improving sports achievements in order to improve the nation's name in the international arena. Therefore the development and development of sports need to get good attention through systematic planning and implementation in regional development, to the national level.

Football is a sport that is already popular in Indonesia. Either as entertainment, starting from training to improve body condition or as an achievement to defend schools, villages, regions and countries. That we can see so many people who like him either as spectators or directly as players, ranging from urban to rural, from children to parents. Their reasons are also varied, there are people who just fill their free time, just to exercise until they want to achieve high achievements, also with the increase in associations or soccer clubs, both football schools, Pusdiklat and so on. With the increase in football associations, this not only happens in cities but also increases in villages. So it can be said that football is a popular sport.

Football game is a team game that demands good and neat cooperation in a team. Therefore teamwork is a football game requirement that must be met by every team or team that wants to win.

Victory in soccer will only be achieved through good teamwork. Victory cannot be won individually in team play. Besides that, each individual or player must have good physical condition, good basic techniques and good mentality. Apart from that soccer also involves all the basic techniques in football games such as: dribbling, kicking the ball (short and long shooting), heading the ball (heading), passing the ball (passing), stopping the ball (trapping), throwing to in (throw-in), deceptive tricks and turns (tricks and turns), rock the ball (juggling), and techniques to catch and ward off the ball for the goalkeeper (goalkeeper) [2].

A soccer player must possess and master the basic techniques of good play, especially techniques with the ball, which is needed when attacking which is called dribling. Dribling is an important factor and one of the main factors in the game of football, because without mastering dribling properly it is difficult for players to develop their game. Dribling aims to carry out attacks by passing opposing players and also dribling is beneficial for the player or team to obtain victory [3].

Each player has different dribling abilities, this is due to several factors, one of the factors in dribbling the ball is the agility of body movements and endurance in making every movement in the game of football. 
Based on the writer's observation, the soccer team of SMP Negeri 6 Kerinci has recently experienced a decline in performance, this is due to some weaknesses in the players, one of which is the technique when doing dribling that is not in accordance with the desired goals when playing. This weakness is also influenced by the low motivation of students who take part in the training and the impact is when participating in the match, players who only have the desire to play but are not equipped with enough basic techniques to support team play, this is proven by the fact that they have never won a match or tournament that has never often held both between schools, and district level, and other general championships.

It is very unfortunate that if left unchecked, many impacts will be caused if not addressed as early as possible. Exercises that can improve the ability of players need to be held in order to have a good basis for playing football. One of the exercises to improve player dribling skills is circuit training. This exercise is formed in a program that can make players interested in doing exercises.

Players practice circuit training with exercises that start from light to difficult levels, each exercise item affects other training items, so players are challenged to do another exercise. Circuit Training is expected to be able to make players focus on doing the exercises.

So from the description above the author is interested in conducting research with the title "The Effect of Circuit Training Exercises Against Dribling Ability in Football Players Aged 12-14 Years at Kerinci 6 Public Middle School".

\section{Type of Research}

\section{METHODOLOGY}

Based on the issues to be discussed, this research is experimental in nature which aims to reveal the causal relationship between knowing more about the effects of training. As stated by [4] experimental research is "The research design that provides the most rigorous and careful testing of hypotheses. Although comparative correlational and causal designs can express relationships between variables, experimental designs are used specifically to express causal relationships.

To simplify the steps that must be taken in research, we need a rule that must be used as a guide for the author so that research does not come out of the rules that have been set so that the results obtained in accordance with the expected goals.

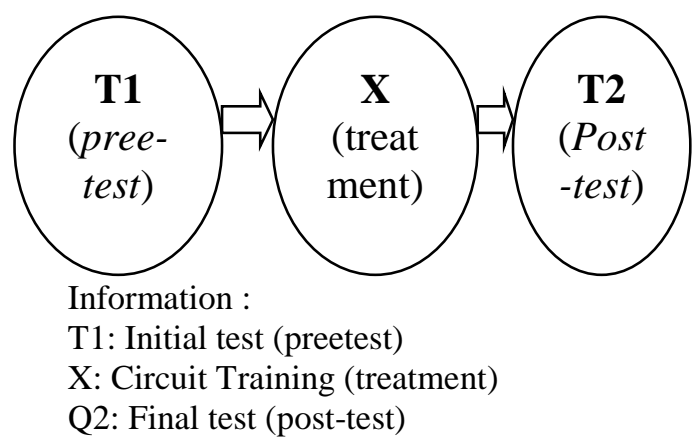

\section{Population and Sample}

\section{Population}

The study population is the whole subject to be investigated. This is consistent with the opinion raised by [5], namely "The population is the whole subject of research". From this statement it is concluded that the intended population is all individuals who will be the object in a study. The population in this study were male students who participated in soccer extracurricular activities at SMP Negeri 6 Kerinci with a total of 38 people.

\section{Sample}

The sample is the smallest part of the population that is the subject of research, this is in accordance with the opinion issued by [5] that: "The sample is a portion or representative of the population to be examined".

In this study the sampling technique is done by means of purposive sampling. Where Purposive Sampling is taking subjects randomly according to criteria such as: age, sex, height, weight, etc. [5].

In this study sampling itself has considerations including: age 12-14 years, routine in following the training. The sample in this study amounted to 30 people.

\section{Research variable}

Variables as symptoms vary, for example sex, (malefemale); body weight, (40kg, $50 \mathrm{~kg}, 60 \mathrm{~kg}$, etc.), height $(180 \mathrm{~cm}, 168 \mathrm{~cm}, 175 \mathrm{~cm}$, etc.) [4].

According to [5], variables are the object of a study. Variables in a study are divided into two namely independent variables and dependent variables.

In this study the variables are divided into:

Independent variable: Circuit Training $(\mathrm{X})$

Dependent variable: Dribling ability (Y)

\section{Data Types and Sources Data Types}

Based on the objectives to be achieved as well as efforts to express problems relating to the effect of circuit training exercises on improving the ability of dribling football players aged 12-14 years in SMP Negeri 6 Kerinci, the type of data used in this study is primary data, that is data directly in take and get from the sample by doing the test. The test is a dribling test. And secondary data that is not directly obtained from information that supports research.

\section{Data source}

In accordance with the purpose of this study, the source of the data obtained from the implementation of the dribling test conducted by the sample in this study.

\section{Research Instruments}

Instrument means research tools in the form of a set of tests to collect data as processing material. The instrument is carried out by means of a sample conducting a dribling test to take the fastest time possible to see the test taker's ability to pass the given obstacle and record the results achieved by the test participant past the obstacle.

After the pree-test and the results are obtained then treated with circuit training exercises for 18 meetings and ended with a post-test to see the results whether there is an 
increase in dribling skills in players aged 12-14 years in SMP Negeri 6 Kerinci.

Tools used:
a. Ball
b. Stop Watch
c. 6-10 obstacles (stick or javelin).

\section{Data Collection Techniques}

To get the data in this study, two tests were carried out namely the initial test (pree test) and the final test (post-test), namely the ball dribbling test, the initial test (pree test) was carried out before the soccer players of SMP Negeri 6 Kerinci did circuit training and the final test (post test), carried out after the Kerinci 6 Junior High School players performed circuit training exercises.

The data collection techniques are as follows:

\section{Dribbling test}

a. Before conducting Circuit training exercises, an initial test is first performed to see the player's dribling skills. After getting the initial test results then given treatment for 18 meetings, then the final test is carried out to see the changes or effects of the treatment given. The aim is to measure and determine dribbling skills with rapid foot movements accompanied by changes in direction.

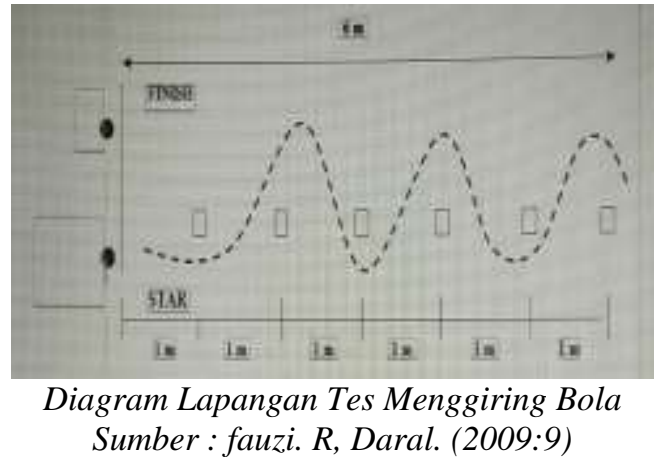

2. How to score:

a. The test taker stands behind the starting line with a ball in the starting line.

b. On the signal "yes" or the sound of a whistle, test participants run while dribbling the ball as fast as possible past all obstacles in a zig-zag manner.

c. Method of assessment: Results taken are the time taken from start to finish in tenths of a second.

\section{Data analysis technique}

From the proposed hypothesis, the data analysis was performed using t-test to see the results of the experiment training circuit training on increasing the ability of dribling using pre-test and post-test one group design research designs, before t-test analysis was first carried out data frequency analysis, test normality and homogeneity variance test. [6]

After analyzing data frequency, normality test and homogeneity variance test, a hypothesis test is performed to find out whether circuit training exercises have an effect on increasing the ability of Dribling football players aged 12-14 years at SMP Negeri 6 Kerinci. Hypothesis testing uses t-test at $95 \%$ confidence level or $\mathrm{a}=0,05$. So for the t-test used to see the results of the treatment used the following formula:

$$
t=\frac{M d}{\sqrt{\frac{\sum x^{2}-d}{N(N-1)}}}
$$

Information:

Md : Mean of the difference between the pree test and the post-test

$\mathrm{Xd} \quad$ : Deviation of each subject (d - Md)

$\sum \mathrm{X} 2 \mathrm{~d}$ : Number of quadrants deviation

$\mathrm{N} \quad$ : Subject in the sample

D.b : Determined by N-1

\section{RESULTS AND DISCUSSION}

The results of this study will discuss some important points based on the results of data analysis. In detail the results of the study will discuss the description of research data, analysis test requirements, data frequency, and research hypothesis testing.

The results obtained from the dribling ability test in football games, which were started by conducting a Pree test (initial test), then given treatment for 18 meetings and ending with a Post-test (final test) in the experimental group totaling 30 samples obtained the initial test results and final test.

In carrying out this study, the test was carried out 2 times, namely the initial test and the final test. The initial test carried out aims to see the initial ability of a person before being given treatment and the final test carried out aims to see the extent of the Effect of Circuit Training Exercises on the ability of dribling football players aged 12-14 years at SMP Negeri 6 Kerinci. The exercise is done with a frequency of 3 times a week for 18 meetings.

To see the results of the experiment can be done by analyzing the final test data and the initial test of the ability of the sample with zig-zag dribling test with the t-test analysis of all the test criteria if the tcount is greater than ttable, this means that there are significant differences and vice versa if the tcount is smaller from t table, this means that there are no significant differences.

In the preliminary data obtained from the results of the initial dribbling test for football players in SMP Negeri 6 Kerinci with a total of $\mathbf{5 0 5 . 1 9}$ seconds, the average time is obtained, the results of the total time divided by the number of samples with the results obtained, namely $\mathbf{1 6 . 8 4}$ seconds. Then the best time obtained from the sample is $\mathbf{1 4 . 6 3}$ seconds.

Meanwhile, the data obtained from the results of the final test of dribbling of football players in SMP Negeri 6 Kerinci with a total number of $\mathbf{4 8 7 . 8}$ seconds, obtained an average time that is the results of the overall time divided by the number of samples with the results obtained is $\mathbf{1 6 . 2 6}$ seconds. Then the best time obtained from the sample is 13.86 seconds. From the results of data analysis in this study, there is an effect of Circuit Training Training on the Dribling Ability of Football Players Aged 12-14 Years Old in Kerinci 6 Public Middle School. To test this hypothesis is accepted or rejected, the authors compare the results of the 
average initial test data and final test using the t-test analysis. before the t-test is performed first, frequency analysis, normality and homogeneity variance data tests are performed. From the statistical analysis on the test, it shows that the Circuit Training Exercise can improve the ability of the sample to do football dribling, this is concluded based on the results of the analysis of quasi experimental $t$ test data obtained $t_{\text {hitung }}=14,519$ the amount is compared with the amount $t_{\text {table }}$ with $d f ; n-1(30-1=29)$. To a significant degree $\alpha=0,05$. is 1,699 . therefore $t_{\text {hitung }}<t_{\text {tabel }}$ then the alternative hypothesis (Ha) presented in this study is accepted.

That between the initial test and the final test has different results, with the meaning of the word there is an increase in the ability of dribling in soccer after doing Circuit Training Exercises on the soccer team of SMP Negeri 6 Kerinci.

Based on the results of the study above, it can be concluded that to improve the dribling ability of football games can be done by conducting Circuit Training Exercises. This certainly occurs because of the good cooperation between the trainer and the trained and high awareness to do the exercises based on the program that has been set. Because without awareness to practice certainly will not achieve the expected results.

\section{CONCLUSION}

From the data analysis and hypothesis testing, it can be concluded that there is a significant influence on the Circuit Training Exercise on improving the ability of dribling football players aged 12-14 years at SMP Negeri 6 Kerinci.

\section{REFERENCES}

[1] Undang-undang RI No 03. Sistem Keolahragaan Nasional. Yogyakarta: Pustaka Yudisti. 2005.pp.12-32.

[2] M, Danny. "Dasar-dasar Sepak Bola". PT. Pakar Raya, Jakarta. 2007.pp.44-54.

[3] Dalar, Fauzi. "Petunjuk Pelaksanaan Tes Keterampilan Sepakbola Usia 10-12 Tahun". Pusat Pengembangan Kualitas Jasmani, Jakarta. 2009.pp.11-43.

[4] Winarno. "Metodologi Penelitian Dalam Pendidikan Jasmani". Malang: Media Cakrawala Utama Press. 2011.pp.33-55.

[5] A, Suharsimi. "Prosedur penelitian". Jakarta: PT. Rineka cipta. 2006.pp.43-55.

[6] Sudjana. "Metoda Statistika". Bandung: Tarsito. 2002.pp.23-51. 